\title{
Stephan Lessenich: Ponovno izumljanje socialnega: Socialna država v prožnem kapitalizmu
}

\author{
Ljubljana: Založba Krtina, 2015, 215 strani
}

Tuja dela o socialni državi so redko prevedena v slovenski jezik, čeprav se v zadnjih letih o njej veliko govori v kontekstu preoblikovanja socialne države v t. i. delovno državo oz. z delom pogoje(va)no blaginjo (Workfare). ${ }^{1}$ Obravnavana knjiga je prispevek $\mathrm{k}$ razumevanju teh sprememb na več ravneh - na makro ravni s pojasnjevanjem zgodovine razvoja socialne države in umeščanjem v sedanje oblike kapitalizma, na mezo ravni $z$ razlago socialne politike in na mikro ravni s pojasnjevanjem učinkov na naše življenje. Poleg tega se avtor osredotoča na kontekstualizacijo in pojasnjevanje poglavitnih konceptualnih sprememb, s katerimi se sociologija ukvarja že nekaj desetletij, v zadnjem pa jo skorajda docela okupirajo.

Knjiga je razdeljena na pet poglavij. V prvem se Lessenich ukvarja s spreminjanjem socialne države, o kateri govori kot o socialnem dejstvu, ki je oblikovalo družbo vse od delavskih gibanj 19. stoletja dalje. Socialne politike so vplivale na razvoj družb in $\mathrm{k}$ napredku prispevale vsaj toliko kot gospodarstvo. Socialna država je spodbujala tako delovanje skupnosti in razvoj kolektivne blaginje kot avtonomijo posameznikov, čeprav je povzročala tudi izključevanje in marginalizacijo skupin, ki so jih socialne politike spregledale ali jih niso vključile. Avtor poudari, da socialna država ni le »sekularizirana različica krščanske karitas, ni le prostor in trdnjava pomoči, solidarnosti in dobrodelnosti, temveč (vselej) tudi orodje socialnega uravnavanja, nadzorovanja in discipliniranja (str. 20). Zato je naloga znanstvene obravnave, da ohranja distanco do socialne politike, katere pomen je v uresničevanju »družbenih idealov«, ki se skozi zgodovino spreminjajo. Naloga sociologije je, da to »opiše, razume in pojasni«. Po tem zgledu najprej pod vprašaj postavi govor o krčenju, razgradnji in uničevanju socialne države, ki naj bi bil značilen za kritično družboslovje. Meni, da podatki kažejo še vedno visoke odstotke BDP, ki jih nacionalne države namenjajo tako za dajatve kot za storitve. Tudi govor o neoliberalizaciji politik se mu zdi povsem pretiran in celo zavajajoč, ker meni, da ne gre le za liberalizem. Kasneje v knjigi izpostavi, da so se $\mathrm{v}$ Nemčiji (in tudi pri nas) glavne spremembe dogajale $\mathrm{v}$ času

1 Prevod besede je ponesrečen, ker gre za skovanko, izpeljano iz angleške besede welfare, vendar zaenkrat ni mogoče najti ustreznejšega prevoda brez opisnega prevajanja pomena. V slovenščini koncept prevajajo tudi kot država dela, vendar je ta prevod še slabši, saj je večpomenski in ne odraža dejanskih sprememb. Lessenich govori o »aktivacijski« socialni državi, ki ni prevod workfare, vendar dobro ujame naravo sprememb. 
socialdemokratskih vlad. Da ne gre za liberalistične politike, utemeljuje z dejstvom, da se država ne umika, le temeljito spreminja svoje delovanje in podobo, kar poimenuje »neosocialnost«. Neosocialna država odraža duh kapitalizma, ki v sedanjem času na novo izumlja socialno, ki naj bi izžarevalo glavne značilnosti tega duha, to je aktivnost, mobilnost, prožnost in gibljivost. Evropska birokracija posledično sedaj govori o aktivacijski, investicijski, preventivni in preprečevalni socialni politiki. Aktivacijske socialne države ne zanima blaginja posameznikov ali gospodinjstev, temveč blaginja namišljene nacionalne skupnosti. Posameznik je socialen, če kaže aktivno držo in odgovornost do te skupnosti.

$\mathrm{V}$ drugem poglavju avtor predstavi nastanek in razvoj socialne države na dimenzijah modernizacije, normalizacije, prerazdelitve, varstva, integracije in urejanja odnosov. Meni, da socialna država ni le rezultat in učinek, temveč vzrok in pogoj za družbeno modernizacijo. $\mathrm{Z}$ obstojem diferenciranega sistema socialne varnosti je postal družbeno izvedljiv diferenciran sistem produkcije in distribucije ekonomskih dobrin. Zaradi obstoja tega sistema (pokojninski sistem skrbi za stare, zdravstvo za vse, izobraževanje za mlade, socialne službe za revne itd.) se lahko kapitalistična ekonomija ukvarja zgolj z dobičkom, produktivnostjo ali koristjo. $\mathrm{Na}$ individualni ravni so ljudje v tržnih gospodarstvih, ki so urejena kot socialne države, vpeti v sistem institucionalnih pričakovanj, zahtev in dolžnosti, ki so rezultat socialnih politik. Tako se življenjski poteki zgodovinsko normalizirajo na relaciji izobraževanjedelo-upokojitev in mladost-partnerstvo-družina-starost. Prerazdelitvena funkcija socialne države je v dekomodifikaciji, ki pa jo Lessenich postavi pod vprašaj, saj naj bi imeli pravico do nadomestila za mezdo le tisti, ki so že bili v mezdnem delu. Tako po njegovem mnenju socialna država ustvarja nove neenakosti. Drug problem prerazdelitve je nepreglednost tokov, po katerih poteka, in vprašanje, koga ti tokovi sploh dosežejo. Varnost veže na sistem zavarovanja, ki ga večinoma vodi država, sama družba pa postane "zavarovalna družba«. Gre za kolektivizacijo varnosti in socializacijo odgovornosti. Socialno zavarovanje temelji na prispevkih zaposlenih, vendar imajo koristi in pravice tudi tisti, ki nimajo zaposlitve. Na nek način gre za prisilno plačevanje, vendar z vključenim dobičkom, saj so tisti, ki prispevke plačujejo, do sredstev iz zavarovanja lahko upravičeni tudi v primeru, ko izgubijo zaposlitev. Gre torej za integracijo delnih skupin socialno diferencirane družbe. Socialna država tako omogoča delitev tveganja med tujci in podaljša čas delitve tveganja izven biografskega časa osebe, za katero gre (medgeneracijska pogodba). Pri tem ne gre pozabiti, da je sistem zavarovanja primarno skrb za lastne interese. Te dimenzije kažejo na to, da je socialna država v bistvu način urejanja odnosov znotraj nacionalnih držav. Poglavje nadaljuje $z$ opisom štirih tipov razlag nastanka in razvoja socialne države, ki jih na tem mestu ne bomo povzemali. 
Tretje poglavje govori o zlati dobi socialne države in Esping-Andersenovih tipologijah. Opozori na preobrazbe, ki jih je Esping-Andersen delal na svojem modelu tipologij glede na kritike in glede na politike. Kar ostaja nespremenjeno, je dejstvo, da gre pri socialni državi v vsakem sistemu za institucionalno in institucionalizirano urejanje odnosov. Po zlati dobi socialne države, ki je trajala približno do konca sedemdesetih, začnemo govoriti o premočni »skrbstveni državi«. V zvezi s tem omenja predvsem Luhmannovo tezo o "avtomobilni« socialni državi oz. državi na lastni pogon. Država naj bi bila podobna vodnemu stolpu, v katerega se črpajo sredstva, nanj pa se priključijo vsi, ki ta sredstva potrebujejo. S tem se preobremeni in lahko celo »samo sebe potroši«. Tretje teoretsko ogrodje je Offovo delo, ki govori o strukturnih problemih socialne države. Gre za protislovja med izpolnjevanjem ekonomskih potreb in socialnih zahtev. Ekspanzija socialne države jemlje vrednost iz procesa akumulacije, vendar hkrati ureja interese ekonomske produkcije s politiko dela in dejavnostjo na področju infrastrukture.

$\mathrm{V}$ četrtem poglavju se Lessenich usmeri v sedanji čas in razdela svoj koncept aktivacijske socialne države. Spremembe, ki jih narekuje sedanji »prožni« kapitalizem, so povzročile »aktivacijski« preobrat. Gre za spremembe v vladanju, kar podkrepi s Foucaultovim konceptom governmentality. V središču novega vladanja je prehod od javne varnosti k zasebni, od kolektivnega upravljanja tveganj k individualnemu, od socialnega zavarovanja k lastni odgovornosti, od državne oskrbe k skrbi zase. Glavni cilj teh sprememb je ustvarjanje odgovornih posameznikov, ki so sposobni izračunati tako individualne kot družbene stroške svojih ravnanj (podjetniška subjektivnost). Posamezniki morajo imeti spretnosti, znanja in sposobnosti, da se nenehno prilagajajo, so aktivni in mobilni ter vedno delujejo racionalno. Opustitev takih ravnanj je nemoralno dejanje, razumljeno kot namensko povzročanje škode ne le sebi, temveč tudi »skupnosti«. Socialna politika postane politika korenčka in palice, spodbud in zahtev, ki jih spremlja vrsta retoričnih figur, kot je uporaba metafor, premeščanje in spreminjanje pomenov ter množična uporaba poenostavitev kompleksne realnosti, ki jo znajo sedanji politiki zvesti na zelo preproste obrazce o dobrem in zlu, lenuhih in pridnih, gospodinjski logiki pri trošenju denarja in podobno. Lessenich govori o »magičnih floskulah«. Aktivacijska država je rezultat teh poenostavitev, z njimi se oplaja in hrani. Ena od floskul je tudi tista o investirajoči državi, ki ima za svoj cilj investicije v to, kar se lahko obrestuje, zato so upravičene le politike do otrok (in njihovih mater), ker jih še vedno lahko oblikujemo in vplivamo na njihove življenjske poteke $\mathrm{z}$ omejevanjem ter določanjem želja in izbir. ${ }^{2}$ Vedno več je tudi govora o aktivnem staranju, ki je nekakšen medgeneracijski koncept, saj se ne nanaša le na stare

2 Že nekaj let je vroča tema EU revščina otrok, kot da je to izoliran fenomen in ne rezultat revščine otrokovih staršev. $\mathrm{Z}$ revščino otrok se ukvarjajo, kot da bi jo bilo mogoče odpraviti, ne da bi naslovili tudi revščino staršev. 
ljudi, temveč na vse nas, ki bomo slej ko prej ostareli in se moramo na to pripravljati v sedanjosti. Zavračanje aktivne drže je nemoralno dejanje, saj je dolžnost starih ohranjanje zdravja in prožnosti, da ne bi bili breme socialnih in zdravstvenih blagajn.

V zadnjem poglavju avtor govori o prihodnosti socialne države. Opozori na to, da so navidezna protislovja $\mathrm{v}$ sedanjem kapitalizmu kapitalizmu v resnici imanentna. Po eni strani zahteva aktivnost in mobilnost, po drugi pa oboje nadzira, da bi ločil pleve od zrnja. »Sprožati, spodbujati in izkoriščati mobilnost in jo hkrati kanalizirati in zavirati, da bi preprečili nezaželeno, je večni tok stvari v kapitalistični družbi mezdnega dela« (str. 147). Našteje celo vrsto primerov, ko mobilnost ni zaželena. Navaja primere ljudi brez papirjev (kar je pri nas aktualno že vse od izbrisa) in migrante. Poglavje precej esejistično zaključi z ugotovitvijo, da je največja izguba, ki jo povzroča aktivacijska socialna država, izguba avtonomnega posameznika, ki ima možnost razvijati lastne predstave o mobilnosti, fleksibilnosti in produktivnosti. Vendar je sedanji konsenz o aktivni družbi precej razširjen, zato lahko govorimo o družbenem soglasju pri nastajanju projekta aktivacije.

Konceptualni okvir knjige je zanimiv in inovativen. Ne dolgočasi nas z običajnimi tipologijami socialne države, temveč se problema loti s povsem druge perspektive - ne zgolj s socialno-politične, temveč predvsem s sociološke, zato se bolj kot s tipologijami ukvarja s procesi in strukturami. Ne čuti potrebe, da bi svoje analize podkrepil s tabelami in grafi oz. številkami, kar je prednost dela, saj njegov namen ni dokazovati, da ima prav, temveč razmisliti, kaj je zadaj, za kaj pri vsem skupaj sploh gre, kakšno je razmerje med posamezniki in državo ter kako se vse skupaj spreminja v sedanjem času. Ni mogoče reči, da nam je Lessenich ponudil kaj bistveno novega, čeprav nas je okrcal pri pretirani rabi besede neoliberalizem in pretiranem opozarjanju na propad socialne države. V tem se z njim strinjam, saj gre predvsem za proces zelo temeljitega preoblikovanja, ki odraža družbene spremembe nasploh. Knjiga je pomemben prispevek $\mathrm{k}$ razumevanju pretvorbe sedanjega kapitalizma v socialne politike. Naj opozorim še na spremno študijo k slovenskemu prevodu, ki jo je spisal Srečo Dragoš in jo lahko vidimo tudi kot dopolnitev knjige, saj nekatera spoznanja sistematizira in izlušči glavne poante knjige, ki jih aplicira na slovenske razmere. 